\title{
Kepemimpinan Transformasional, Motivasi Dan Disiplin Kerja dan Pengaruhnya Terhadap Kinerja (Studi pada Pegawai Di Kantor Kecamatan Ngunut Kabupaten Tulungagung)
}

\author{
Widya Citraningtyas \\ Magister Manajemen Universitas Islam Kadiri
}

\begin{abstract}
This research aims to: analyse the influence of Transformational Leadership among variables on performance clerk; Analyse the influence of motivational variables on performance among employees; Analyse the influence of the working Discipline among variables on performance clerk; Analyzing simultaneously the significant influence of transformational leadership, motivation and discipline work against employee performance; analyse the influence of the most dominant Transformational Leadership among variables, motivation and discipline work against the performance of employees.

This research uses Descriptive Quantitative. the population in this research is Ngunut Subdistrict Office clerk. Tulungagung district. The researcher does not specify a sample, because all members of the population will be examined. The technique is a method of data collection now. In this study, researchers used the software (software), Microsoft Office Excel 2007 to carry out a descriptive and statistical analysis software (software) Statistical Packeage for Social Sciences (SPSS) for Windows version 21.0 to carry out the test, test the classical, hypothesis testing and multiple linear regression analysis, , The results showed that there were simultaneous or partially significant effects between Transformational Leadership variable, motivation and discipline work against the performance of employees: as for the most dominant influence i.e. variable Discipline work.
\end{abstract}

Keyword: Transformasional Leadership, motivation, work dicipline employee performance

\section{Latar Belakang Teoritis}

Kinerja Sumber daya manusia juga dipengarui oleh gaya kepemimpinan dari pemimpin. Seorang pemimpin juga harus mempunyai kemampuan yang cukup memadai sehingga dapat memimpin dan meningkatkan kinerja pegawai yang dipimpinnya. Kepemimpinan adalah proses mempengarui atau memberi contoh pada pengikut-pengikutnya lewat proses komunikasi dalam upaya mencapai tujuan organisasi (Rivai:2014). Kepemimpinan transformasional merupakan proses memimpin dengan mengambil sikap, perilaku dan untuk meningkatkan kesadaran pengikut tentang sesuatu yang benar, mengembangkan motivasi kinerjanya, serta mendorong mengaktualisasikan dirinya melampaui minat pribadi demi kesejahteraan bersama. Melalui kepemimpinan ini dapat meciptakan ruang bagi pemimpin dan pengikutnya untuk saling bekerja sama mencapai tujuan (Umiarso:2018)

Keberhasilan suatu instansi tergantung Sumber Daya Manusia dari Camat dan Seluruh pegawainya, Selain itu Motivasi juga mempengaruhi kinerja Pegawai. Motivasi merupakan suatu kondisi yang mendorong atau menjadi sebab seorang perbuatan/kegiatan yang berlangsung secara sadar (Nawawi : 2016). Peneliti Wawan (2015) mengemukan bahwa motivasi berpengaruh signifikan terhadap kinerja sedangkan I Wayan (2015) Motivasi berpengaruh Positiv terhadap Kinerja, Windy (2018) mengemukakan bahwa motivasi merupakan factor yang berpengaruh paling dominan terhadap kinerja karyawan, Evawati (2016) mengemukakan bahwa adanya pengaruh yang signifikan antara variable disiplin dan motivasi kerja terhadap kinerja pegawai, Sugeng Sutrisno (2013) mengemukakan bahwan disiplin kerja dan motivasi kerja berpengaruh positif signifikan terhadap kinerja pegawai.

\section{Kepemimpinan Transformasional}

Kepemimpinan (Leadership) adalah kemampuan atau kekuatan yang digunakan oleh pemimpin untuk menggerakkan para pengikitnya untuk mencapai visi atau tujuan organisasi. Ada berbagai pendekatan untuk menggerakkan pengikut, menjadi teladan menerapakan Reward, memaksa dengan hukuman dan Public speaking, semua pendekatan tersebut bisa diterapkan sesuai tergantung situasi dan kondisinya (Timotius:2015). Kepemimpinan adalah proses mempengarui atau memberi contoh 
pada pengikut-pengikutnya lewat proses komunikasi dalam upaya mencapai tujuan organisasi (Rivai:2014). Kepemimpinan transformasional merupakan proses memimpin dengan mengambil sikap, perilaku dan untuk meningkatkan kesadaran pengikut tentang sesuatu yang benar, mengembangkan motivasi kinerjanya, serta mendorong mengaktualisasikan dirinya melampaui minat pribadi demi kesejahteraan bersama. Melalui kepemimpinan ini dapat meciptakan ruang bagi pemimpin dan pengikutnya untuk saling bekerja sama mencapai tujuan (Umiarso:2018)

\section{Pimpinan}

Transformasional

(Transformational leaders) menginspirasi para pengikutnya untuk mengenyampingkan kepentingan pribadi mereka demi kebaikan organisasi dan mereka mampu memiliki pengaruh yang luar biasa pada diri pengikutnya. Pimpinan juga menaruh perhatian terhadap kebutuhan pengembangan diri para pengikutnya; mengubah kesadaran para pengikut atas isu isu yang ada dengan cara membantu orang lain memandang masalah lama dengan cara yang baru; serta mampu menyenangkan hati dan menginspirasi para pengikutnya untuk bekerja keras guna mencapai tujuan bersama (Robbins: 2015)

\section{Motivasi}

Umar (2010) mengutip dari teori klasik Taylor yang menyatakan bahwa motivasi bekerja hanya untuk dapat memnuhi kebutuhan dan kepuasan biologis saja, yaitu dapat mempertahankan kelangsungan hidup. dari teori tersebut dapat disimpulkan bahwa semakin tinggi standar kebutuhan dan kepuasan yang diinginkan maka semakin giat seseorang untuk melakukan pekerjaannya. Motivasi sebagai konsep yang menguraikan tentang kekuatan-kekuatan yang ada pada diri pegawai yang memulai dan mengarahkan perilaku (Gibson:2011). Muchdarsyah (2010) berpendapat bahwa motivasi merupakan keadaan kejiwaan dan sikap mental manusia yang memberikan energi, mendorong kegiatan atau gerakan mengarah atau menyalurkan perilaku kearah mencapai kebutuhan yang memberikan kepuasan atau mengurangi ketidak seimbangan.

Ada dua Jenis Motivasi, yaitu (1) motivasi positif, motivasi yang menimbulkan harapan yang sifatnya menguntungkan atau menggembirakan bagi pegawai, misalnya gaji, tunjangan, failitas, karier, jaminan hari tua, jaminan kesehatan, jaminan keselamatan dan semacamnya; (2) Motivasi negative, motivasi ynag menimbulkan rasa takut, misalnya ancaman, tekanan, intimidasi dan sejenisnya (Sarinah : 2017)

\section{Disiplin Kerja}

Disiplin merupakan tidakan manajemen untuk mendorong para anggota organisasi untuk memenuhi tuntutan berbagi ketentuan (Siagian : 2015). Sedangkan menurut Manullang (2014) mengemukakan bahwa hakikat dari kepatuhan adalah disiplin yaitu melakukan apa yang sudah disetujui bersama antara pimpinan dan pegawai, baik persetujuan tertulis, lisan atau berupa peraturan tak tertulis kebiasaan maupun budaya.

Suatu sikap disiplin tidak muncul dalam waktu sekejap atau singkap akan tetapi diperlukan pengarahan dan pembinaan pembninaan dalam waktu yang terus menerus. Tidak harus menggunakan kekerasan bisa dengan suatu ketegasan yang diberikan oleh seorang pemimpin terhadap pegawainya. Disiplin adalah kegiatan manjemen untuk menjalankan satndar standar organisasional. Ada dua tipe kegiatan kedisiplinan yaitu preventif dan korektif. Dalam pelaksanaan disiplin, untuk mendapatkan seperti hasil yang diharapkan, maka pimpinan dalam usahanya menggunakan pedoman tertentu sebagai landasan pelaksanaan (Handoko:2011).

\section{Kinerja Pegawai}

Mangkunegara (2010) mendifinisikan kinerja Sebagai "hasil kerja secara kualitas dan kuantitas yang dicapai oleh seseorang pegawai dalam melaksanakan tugasnya sesuai dengan tanggung jawab yang diberikan kepadanya".Kinerja seorang Pegawai merupakan kombinasi dari kemampuan, usaha dan kemmapuan dapat dinilai dari hasil kerjanya dengan demikian kinerja pegawai dapat dipahami sebagai kualitas dan kuantitas hasil kerja (output) individu dan kelompok yang dicapai dalam suatu periode waktu tertentu memlalui kombinasi kemampuan, usaha dan kesempatan yang tersedia, Kinerja pegawai adalah suatu hasil kerja yang dicapai seseorang dalam melaksanakan tugas - tugas yang dibebankan kepadanya yang didasarkan atas kecakapan, pengalaman dan 
kesungguhan waktu, sebagian besar organisasi, kinerja para karyawan individual menentukan utama factor organisasi (Hasibuan:2015)

Kinerja dapat dinilai berdasarkan kualitas dan kuantitas pekerjaan, kemampuan bekerja sendiri, pemahaman dan pengenalan pekerjaan, serta kemampuan memecahkan persoalan yang dicapai oleh karyawan (Soeprihanto:2017). Handoko (2011) kinerja yang berbeda antara pegawai yang satu dengan pegawai lain secara garis besar dipengarui olegh dua hal yaitu faktor individu dan faktor situasi. kinerja yang dicapai antar pegawai berbeda karena adanya faktor-faktor individu yang berbeda, seperti misalnya adanya perbedaan kemampuan, fisik, motivasi dan faktor individual lain.

\section{Metode}

Dalam penelitian ini peneliti menggunakan model atau bentuk penelitian kuantitatif deskriptif, populasi dalam penelitian ini adalah pegawai Kantor Kecamatan Ngunut kabupaten Tulungagung, penelitian ini tidak menggunakan sampel karena seluruh populasi digunakan sebagai responden, sedangkan teknik pengumpulan data dalam penelitian ini yaitu dengan menggunakan angket.

Variabel yang dianalisis dalam penelitian ini adalah 1) Kepemimpinan Transformasional yang merujuk pada Timotius (2015) didefinisikan sebagai kemampuan atau kekuatan yang digunakan oleh pemimpin untuk menggerakkan para pengikitnya untuk mencapai visi atau tujuan organisasi. Ada berbagai pendekatan untuk menggerakkan pengikut, menjadi teladan menerapakan Reward, memaksa dengan hukuman dan Public speaking, semua pendekatan tersebut bisa diterapkan sesuai tergantung situasi dan kondisinya, serta Apriyanto (2015) didefinisikan bahwa Pemimpin yang trnasformaisonal harus mampu mengajak bawahannya untuk melakukan perubahan dimana perubahan tersebut berpengaruh dari karyawan itu sendiri; 2) Motivasi yang merujuk pada Muchdarsyah (2010) didefinisikan bahwa motivasi merupakan keadaan kejiwaan dan sikap mental manusia yang memberikan energi, mendorong kegiatan atau gerakan mengarah atau menyalurkan perilaku kearah mencapai kebutuhan yang memberikan kepuasan atau mengurangi ketidakseimbangan, serta Apriyanto (2015) didefinisikan bahwa Kinerja seorang dalam melaksanakan pekerjaan salah satunya ditimbulkan dan dipengarui oleh motivasi individual; 3) Disiplin Kerja yang merujuk pada Siswanto (2013) didefinisikan bahwa disiplin kerja adalah suatu sikap menghargai, menghormati patuh dan taat terhadap peraturan yang berlaku baik yang tertulis maupun yang tidak tertulis serta sanggup menjalankan dan tidak mengelak untuk menerima sanksi - anksinya apabila melanggar tugas dan wewenang yang diberikan, serta Susantie (2012) didefinisikan bahwa Seorang Karywan yang memiliki kinerja yang tinggi dan baik dapat menumjang tercapainya tujuan dan sasaran yang telah ditetapkan oleh perusahaan; 4) Kinerja Pegawai yang merujuk pada Hasibuan (2015) didefinisikan bahwa Kinerja seorang Pegawai merupakan kombinasi dari kemampuan, usaha dan kemmapuan dapat dinilai dari hasil kerjanya dengan demikian kinerja pegawai dapat dipahami sebagai kualitas dan kuantitas hasil kerja (output) individu dan kelompok yang dicapai dalam suatu periode waktu tertentu memlalui kombinasi kemampuan, usaha dan kesempatan yang tersedia, Kinerja pegawai adalah suatu hasil kerja yang dicapai seseorang dalam melaksanakan tugas - tugas yang dibebankan kepadanya yang didasarkan atas kecakapan, pengalaman dan kesungguhan waktu, sebagian besar organisasi, kinerja para karyawan individual menentukan utama factor organisasi, serta Apriyanto (2015) didefinisikan bahwa Untuk mengukur tingkat kinerja menggunakan performance system yang dikembangkan oleh atasan dari masing-masing unit kerja.

Dalam penelitian ini menggunakan kuantitatif dengan bantuan software SPSS ver.21.

Data tentang Kepemimpinan Transformasional Kantor Kecamatan Ngunut Kabupaten Tulungagung diperoleh dari hasil angket yang diberikan kepada seluruh pegawai. Angket berisi 20 butir pertanyaan dengan 5 pilihan dan rentang skor 1 sampai 5. Pegawai memilih salah satu jawaban dengan alternative jawaban yang sudah disediakan. Berdasarkan data yang 
diperoleh dapat diketahui bahwa Kinerja pegawai dikategorikan baik. Karena pada rentang 61-80 berjumlah 17 Pegawai. Sehingga dapat disismpulakan bahwa Kepemimpinan Transformasional di Kantor Kecamatan Ngunut Kabupaten tulungagung termasuk pada kategori yang baik.

Data tentang Motivasi Pegawai Kantor Kecamatan Ngunut Kabupaten Tulungagung diperoleh dari hasil angket yang diberikan kepada seluruh pegawai. Angket berisi 20 butir pertanyaan dengan 5 pilihan dan rentang skor 1 sampai 5. Pegawai memilih salah satu jawaban dengan alternative jawaban yang sudah disediakan. Berdasarkan data yang diperoleh dapat diketahui bahwa Motivasi dikategorikan baik. Karena pada rentang 61-80 berjumlah 16 Pegawai. Sehingga dapat disismpulakan bahwa Motivasi Pegawai Kantor Kecamatan Ngunut Kabupaten tulungagung termasuk pada kategori yang baik.

Data tentang Disiplin Kantor Kecamatan Ngunut Kabupaten Tulungagung diperoleh dari hasil angket yang diberikan kepada seluruh pegawai. Angket berisi 20 butir pertanyaan dengan 5 pilihan dan rentang skor 1 sampai 5. Pegawai memilih salah satu jawaban dengan alternative jawaban yang sudah disediakan. Berdasarkan data yang diperoleh dapat diketahui bahwa Disiplin Kerja dikategorikan sangat baik. Karena pada rentang 81-100 berjumlah 17 Pegawai. Sehingga dapat disismpulakan bahwa Disiplin
Kerja Pegawai Kantor Kecamatan Ngunut Kabupaten tulungagung termasuk pada kategori yang sangat baik.

Data tentang Disiplin Kantor Kecamatan Ngunut Kabupaten Tulungagung diperoleh dari hasil angket yang diberikan kepada seluruh pegawai. Angket berisi 20 butir pertanyaan dengan 5 pilihan dan rentang skor 1 sampai 5. Pegawai memilih salah satu jawaban dengan alternative jawaban yang sudah disediakan. Berdasarkan data yang diperoleh dapat diketahui bahwa Kinerja pegawai dikategorikan baik. Karena pada rentang 61-80 berjumlah 17 Pegawai. Sehingga dapat disismpulakan bahwa Kinerja Pegawai Kantor Kecamatan Ngunut Kabupaten tulungagung termasuk pada kategori yang baik.

\section{Analisis Data}

Semua data yang diperoleh data yang diperoleh dalam penelitian ini telah dilakukan uji menggunakan uji validitas dan reliabilitas, semua data yang dihasilkan sudah memnuhi syarat valid dan reliabel. Untuk menganalisis pembahasan dalam penelitian ini menggunakan analisis Regresi Linier Bergana, maka semua data telah dilakukan pengujian asumsi klasik regresi berkenaan dengan Uji Normalitas, Uji Linieritas, Uji heterokedaktisitas dan Uji Multikolinieritas. Semua data dalam penelitian ini telah memenuhi persyaratan Regresi. Ringkasan hasil analisis regresi disajikan dalam table sebagai berikut:

\section{Coefficients $^{\mathrm{a}}$}

\begin{tabular}{|c|c|c|c|c|c|c|c|}
\hline \multirow[t]{2}{*}{ Model } & \multicolumn{2}{|c|}{$\begin{array}{c}\text { Unstandardized } \\
\text { Coefficients }\end{array}$} & \multirow{2}{*}{$\begin{array}{c}\begin{array}{c}\text { Standardized } \\
\text { Coefficients }\end{array} \\
\text { Beta }\end{array}$} & \multirow[t]{2}{*}{$\mathrm{T}$} & \multirow[t]{2}{*}{ Sig. } & \multicolumn{2}{|c|}{$\begin{array}{l}\text { Collinearity } \\
\text { Statistics }\end{array}$} \\
\hline & $\mathrm{B}$ & Std. Error & & & & Tolerance & VIF \\
\hline Constant) & 23.479 & 6.756 & & 3.475 & .002 & & \\
\hline $\mathrm{X} 1$ & .200 & .062 & .342 & 3.247 & .003 & .916 & 1.091 \\
\hline $\mathrm{X} 2$ & .208 & .056 & .391 & 3.737 & .001 & .929 & 1.077 \\
\hline $\mathrm{X} 3$ & .316 & .066 & .502 & 4.791 & .000 & .926 & 1.079 \\
\hline $\mathrm{R}$ & .736 & & & & & & \\
\hline $\mathrm{R}^{2}$ & .705 & & & & & & \\
\hline F-Hitung & 24.109 & & & & & & \\
\hline Sig.F & .000 & & & & & & \\
\hline $\operatorname{Alpha}(\alpha)=5 \%$ & & & & & & & \\
\hline
\end{tabular}

Dari ringkasan table tersebut diatas estimasi model regresi yang didapat adalah sebagai berikut : $\mathrm{Y}=\mathrm{a}+\mathrm{b}_{1} \mathrm{X}_{1}+\mathrm{b}_{2} \mathrm{X}_{2}+\mathrm{b}_{3} \mathrm{X}_{3}$ 


\section{Implikasi \\ Pengaruh \\ Transformasional terhadap Kinerja Pegawai}

Diterimanya hipotesis tentang Pengaruh Kepemimpinan Transformasional terhadap Kinerja Pegawai maka penelitian ini dinyatakan konsinten dan mendukung teori Timotius (2016) menyatakan bahwa Pimpinan Transformasional biasanya bersikap proaktif dalam berbagai hal. Mereka bukan hanya ingin memaksimalkan kinerja, melainkan juga mengembangkan anggota dan Penelitian Wawan Aprianto (2015) menyimpulkan bahwa adanya pengaruh gaya kepemimpinan dan motivasi terhadap Kinerja.

Penelitian ini lebih kuat karena sesuai dengan yang ditemui oleh peneliti bawasannya pimpinan selalu memberikan motivasi serta memberikan perhatian terhadap pegawai guna meningkatakan Kinerja Pegawai kantor Kecamatan Ngunut Kabupaten Tulungagung.

Pengaruh Motivasi terhadap Kinerja Pegawai

Diterimanya hipotesis tentang Pengaruh motivasi terhadap kinerja Pegawai maka penelitian ini dinyatakan konsinten dan mendukung Teori Muchdarsyah (2010) berpendapat bahwa motivasi merupakan keadaan kejiwaan dan sikap mental manusia yang memberikan energi, mendorong kegiatan atau gerakan mengarah atau menyalurkan perilaku kearah mencapai kebutuhan yang memberikan kepuasan atau mengurangi ketidak seimbangan dan Penelitian Rachmawati (2018) dengan kesimpulan bahwa Motivasi Kerja berpengaruh secara signifikan terhadap kinerja Karyawan.

Penelitian ini lebih kuat karena sesuai dengan yang ditemui oleh peneliti bawasannya Motivasi selalu diberikan oleh pimpinan serta pegawai yang ada di Kantor kecamatan ngunut Kabupaten Tulungagung mampu menyelesaikan pekerjaannya sesuai dengan kemampuan yang telah dimiliki.

\section{Pengaruh Disiplin Kerja terhadap Kinerja} Pegawai

Diterimanya hipotesis tentang Pengaruh Disiplin Kerja terhadap kinerja Pegawai maka penelitian ini dinyatakan konsinten dan mendukung Teori Siswanto (2013) menyatakan bahwa disiplin kerja adalah suatu sikap menghargai, menghormati patuh dan taat terhadap peraturan yang berlaku baik yang tertulis maupun yang tidak tertulis serta sanggup menjalankan dan tidak mengelak untuk menerima sanksi - sanksinya apabila melanggar tugas dan wewenang yang diberikan, dan Penelitian Sugeng Sutrisno (2013) yang menyimpulkan bahwa Disiplin Kerja Motivasi Kerja perpengaruh positif dan signifikan terhadap kinerja.

Penelitian ini lebih kuat karena sesuai dengan yang ditemui oleh peneliti bawasannya pegawai sudah melaksanakan tugasnya tepat waktu dengan waktu yang telah ditetapkan oleh instansi.

\section{Kesimpulan}

Terdapat Pengaruh Kepemimpinan Transformasional terhadap Kinerja Pegawai, Terdapat Pengaruh Motivasi terhadap Kinerja Pegawai, Terdapat Pengaruh Disiplin Kerja terhadap Kinerja Pegawai,

\section{Daftar Pustaka}

Rivai. 2014. Kepemimpinan dan Perilaku Organisasi. Jakarta: PT. Raja Grafindo

Nawawi. 2016, Budaya Organisasi Kepemimpinan dan kinerja, jakarta: Kencana

Wawan . 2015. Manajemen Inovasi. Yogyakarta: CV ANDI OFFSET. Dirgantoro

Wayan I. Bagia. 2015. Perilaku Organisasi. Yogyakarta : Graha Ilmu

Sutrisno, Edy. 2013. Manajemen Sumber Daya Manusia, Edisi Pertama, Jakarta : Kencana

Yukl Gary. 2015. Kepemimpinan Dalam Organisasi. Jakarta: Pt.Indeks.

Sondang P. 2015. ... 2015. Manajemen Sumber Daya Manusia. Jakarta: Kencana

Manullang, 2014, Dasar-Dasar Manajemen, Ghalia Indonesia, Jakarta. 